\title{
Identifikasi Faktor Penyebab Perceraian Sebagai Dasar Konsep Pendidikan Pranikah di Kabupaten Banyuwangi
}

\author{
Harjianto, Roudhotul Jannah \\ Program Studi Pendidikan Pancasila dan Kewarganegaraan, Universitas PGRI Banyuwangi \\ Jalan Ikan Tongkol 22 Banyuwangi, 68416 \\ E-mail: hr.bwin@gmail.com, roudhotuljannah1910@yahoo.com
}

\begin{abstract}
Divorcement rate in Banyuwangi district is the second rank in East Java province below Surabaya and third rank in national scale below Indramayu and Surabaya. In 2014, there are 7.106 cases that involve 6.798 couples. This research is aimed to identify the factors that cause divorce high rate in Banyuwangi district. This research uses a qualitative approach with a case study design that using a phenomenological perspective. Purposive sampling method was used and the samples in this research were 40 widows and widowers from 4 sub-districts in Banyuwangi with the highest divorce cases. Data was analyzed with qualitative descriptive analysis. The results shows that divorce was be caused by internal and external factors. Internal factors, namely economy (37,5 percent), responsibility (15 percent), and harmony (17,5 percent). Whereas external factors are infidelity (30 percent). The result of this study will be a recommendation in formulating a prenuptial education learning model based on family and school approaches in Banyuwangi district.
\end{abstract}

Keywords:

divorce; caused factor; education prenuptial

\section{PENDAHULUAN}

Angka perceraian di kabupaten Banyuwangi menempati peringkat kedua tingkat Jawa Timur setelah Surabaya dan ketiga nasional setelah kabupaten Indramayu dan Surabaya. Selama tahun 2014 terdapat 7.106 pasangan yang mendaftarkan perceraian. Angka tersebut lebih tinggi dibandingkan pada tahun sebelumnya yaitu 6.930 pasangan, sedangkan yang sudah menerima putus cerai sebanyak 6.798 pasangan. Sementara itu, yang mengajukan cerai terbanyak adalah perempuan dengan jumlah cerai gugat sebanyak 4.576 orang dan cerai talak yang diajukan laki-laki hanya 2.530 orang. Selain angka perceraian yang cukup tinggi, jumlah dispensasi pernikahan di bawah umur juga meningkat (Kompas 2015).

Perceraian merupakan salah satu bentuk masalah sosial yang ada di masyarakat yang dipandang tidak sejalan dengan tujuan perkawinan. Perceraian bukan hal yang direncanakan, karena perceraian itu dapat terjadi pada siapapun. Banyak faktor penyebab perceraian, di antaranya karena faktor ekonomi, tanggung jawab, gangguan dari pihak ketiga, dan keharmonisan.

Perceraian adalah putusnya hubungan antara suami istri, yang disebabkan ketidakcocokan satu sama lain. Putusnya perkawinan oleh suami atau istri atau atas kesepakatan kedua-duanya apabila hubungan mereka tidak lagi memungkinkan tercapainya tujuan perkawinan. Oleh karena itu, perceraian dapat dilakukan dengan alasan yang kuat dengan hukum perkawinan yang berlaku di Indonesia dituangkan di dalam Undang-Undang Nomor 1 Tahun 1974 dan Peraturan Pemerintah Nomor 9 Tahun 1975.
Kementerian Agama mendapatkan temuan meningkatnya angka perceraian dalam kurun waktu lima tahun terakhir. Temuan itu didapatkan dari hasil penelitian mengenai tren gugatcerai masyarakat muslim di Indonesia yang dijalankan Pusat Penelitian dan Pengembangan Kehidupan Keagamaan Kemenag. Dari dua juta pasangan menikah, sebanyak 15 hingga 20\% bercerai. Sementara, jumlah kasus perceraian yang diputus Pengadilan Tinggi Agama seluruh Indonesia pada 2014 mencapai 382.231, naik sekitar kasus 131.023 dibandingkan tahun 2010 sebanyak 251.208 kasus. Sementara dalam persentase berdasarkan data Badan Peradilan Agama Mahkamah Agung, dalam lima tahun terakhir terjadi kasus cerai gugat mencapai 59$80 \%$. Angka itu didominasi kasus cerai gugat di beberapa daerah seperti Aceh, Padang, Cilegon, Indramayu, Pekalongan, Banyuwangi, dan Ambon (Balitbang Diklat Kemenag 2015).

Save M. Dagun (Sari M.N, Yusri, \& Sukmawati I, 2015) menyatakan bahwa banyak faktor yang menyebabkan terjadinya kasus pertikaian dalam keluarga yang berakhir dengan perceraian. Faktor-faktor ini antara lain: 1) persoalan ekonomi; 2) perbedaan usia; 3) keinginan memperoleh anak; 4) persoalan prinsip hidup yang berbeda, serta faktor lainnya yaitu berupa perbedaan penekanan dan cara mendidik anak dan pengaruh dukungan sosial dari pihak luar.

Penelitian yang mengkaji perceraian di Indonesia telah banyak dilakukan yaitu dengan mengkaji faktor penyebab perceraian. Hasil penelitian di desa Karangbendo, kecamatan Rogojampi, kabupaten Banyuwangi bahwa aspek yang mempengaruhi tingginya angka cerai gugat adalah adanya campur tangan orang 
tua, suami selingkuh, tidak terpenuhinya kebutuhan ekonomi, dan kekerasan dalam rumah tangga. Faktor cerai gugat tersebut di latar belakangi terjadinya perubahan sosial dalam masyarakat, sehingga dapat dilihat adanya pergeseran pola pikir masyarakat khususnya istri dalam memahami perceraian, yaitu kaum isteri saat ini sudah berfikir kritis dalam menuntut hak yang terabaikan karena tidak ada tanggung jawab dari suami (Dias \& Budhy 2013).

Hasil penelitian di Kelurahan Long Ikis, Kabupaten Paser bahwa faktor-faktor penyebab perceraian adalah pertama karena faktor pendidikan, di mana perbedaan pendidikan yang terlampau jauh dapat menimbulkan masalah dalam rumah tangga misalnya saja masalah komunikasi, ada rasa tidak percaya diri dan ada juga yang merasa direndahkan oleh pasangannya, kedua karena faktor usia yang perbedaannya terlalu jauh antar suami istri atau lebih mudanya usia suami dibandingkan usia istri, yang ketiga karena faktor ekonomi yang kurang layak sehingga menyebabkan penghasilan yang tidak dapat memenuhi kebutuhan keluarga, dan keempat karena faktor KDRT (kekerasan dalam rumah tangga) juga adalah penyebab perceraian dalam rumah tangga terutama yang paling banyak menjadi korban adalah dari pihak wanita (Bainah 2013).

Hasil penelitian lain yaitu tentang faktor penyebab tingginya tingkat gugat cerai di kecamatan Payung Sekaki kota Pekanbaru. Berdasarkan hasil penelitian dapat di simpulkan bahwa faktor penyebab tingginya tingkat gugat cerai di kecamatan payung sekaki kota kota pekanbaru adalah (1) kekerasan rumah tangga sebanyak 16 kasus $(44,44 \%)$, perselingkuhan sebanyak 9 kasus (25\%), (3) ekonomi sebanyak 7 kasus (14,44\%), dan (4) adanya campur tangan pihak ketiga(orang tua) sebanyak 4 kasus (11,12\%) (Halimah 2015).

Fenomena yang terjadi dalam kehidupan di masyarakat banyak yang belum memiliki kematangan pikiran dalam menuju ke jenjang pernikahan, baik dari segi faktor usia, komunikasi maupun kemampuan finansial, sehingga tidak jarang permasalahan kerap timbul dalam rumah tangga dan berujung pada perceraian. Upaya menurunkan kasus perceraian dapat dilakukan dengan melakukan penyuluhan ketahanan keluarga kepada kaum laki-laki secara berkesinambungan. Pengetahuan sejak dini tentang kehidupan berumah tangga menjadi penting agar nantinya dapat meminimalisasi angka perceraian (Puspita D.R, Dharma P, \& Idanati R 2016)

Agar harapan pernikahan dapat terwujud dengan baik, maka diperlukan pendidikan pranikah baik dilingkungan keluarga maupun ditingkat sekolah. Program pendidikan pra nikah diharapkan mampu memberi dampak signifikan terhadap kehidupan rumah tangga yang akan dijalani nanti.

Secara umum pendidikan pra nikah berperan sebagai sarana penyampaian informasi dasar yang perlu dipahami sebelum keputusan untuk menikah diambil oleh calon pasangan suami istri, seperti kesiapan lahir dan batin, tujuan yang hendak dicapai, rancangan rumah tangga dan sebagainya; sarana penyampaian informasi tentang kehidupan rumah tangga, seperti cara menghadapi konflik, cara mendidik anak, pemahaman tentang tugas dan tanggung jawab dalam keluarga, dan sebagainya; sarana menyampaikan aturanaturan hukum, khususnya berkaitan dengan kehidupan keluarga. Penelitian ini bertujuan untuk mendeskripsikan faktor penyebab perceraian sebagai dasar konsep pendidikan pranikah di Kabupaten Banyuwangi

\section{METODE PENELITIAN}

Penelitian ini menggunakan pendekatan kualitatif dengan rancangan studi kasus yaitu memakai perspektif fenomenologis. Pemilihan subjek menggunakan purposive sampling, subjek dalam penelitian ini berjumlah 40 orang yang terdiri dari 20 orang janda dan 20 orang duda yang mengalami perceraian yang berada di empat kecamatan di kabupaten Banyuwangi dengan angka kasus perceraian tertinggi, yaitu di kecamatan Tegaldlimo, Tegalsari, Cluring, dan Banyuwangi. Metode yang digunakan dalam analisis data yaitu analisis deskriptif,dengan menggali informasi dari janda dan duda, sehingga ditemukan faktor penyebab perceraian.

Teknik pengumpulan data meliputi: (1) wawancara mendalam; (2) observasi partisipan; dan (3) studi dokumentasi. Data yang terkumpul dari ketiga teknik tersebut dianalisis secara deskriptif kualitatif dengan pendekatan fenomenologis. Selanjutnya data yang telah berhasil dikumpulkan diolah dan dianalisis dengan menggunakan tahapan-tahapan, sebagai berikut: (1) Intuiting. Peneliti menggali fenomena yang ingin diketahui dari partisipan mengenai faktor penyebab perceraian di kabupaten banyuwangi; (2) Analyzing, pada tahap ini peneliti mengidentifikasi arti dari fenomena yang telah digali dan mengeksplorasi hubungan serta keterkaitan antara data dengan fenomena yang ada, data yang penting dianalisis secara saksama. Dengan demikian peneliti mendapatkan data yang diperlukan untuk memastikan suatu kemurnian dan gambaran yang akurat; dan (3) Phenomenological describing. Peneliti mengkomunikasikan dan memberikan gambaran tertulis dari elemen kritikal yang didasarkan pada pengklasifikasian dan pengelompokan fenomena. 
Penentuan lokasi penelitian ini ditentukan secara sengaja (purposive method), yaitu di Kecamatan Tegaldlimo, Kecamatan Tegalsari, Kecamatan Cluring, dan Kecamatan Banyuwangi di Kabupaten Banyuwangi dengan pertimbangan di kecamatan ini tertinggi tingkat kasus perceraiannya, seperti tergambar (Tabel 1).

Tabel 1. Angka perceraian 4 lokasi penelitian

\begin{tabular}{|c|c|c|}
\hline No & Kecamatan & Angka kasus perceraian \\
\hline 1 & Tegaldlimo & 391 \\
\hline 2 & Tegalsari & 152 \\
\hline 3 & Cluring & 149 \\
\hline 4 & Banyuwangi & 149 \\
\hline
\end{tabular}

Sumber: Banyuwangi dalam angka Tahun 2013

\section{HASIL DAN PEMBAHASAN}

Subjek dalam penelitian ini berjumlah 40 orang yang terdiri dari 20 orang janda dan 20 orang duda yang tersebar di empat kecamatan yang memiliki angka perceraian tertinggi di kabupaten Banyuwangi, yaitu kecamatan Tegaldlimo, Tegalsari, Cluring, dan Banyuwangi dengan latarbelakang umur, pendidikan, dan penghasilan yang berbeda-beda. Seperti tergambar pada (Tabel 2), (Tabel 3) dan (Tabel 4).

\section{Tabel 2. Pendidikan}

\begin{tabular}{|c|c|c|c|c|}
\hline Jenjang pendidikan & $\mathrm{L}$ & $P$ & Jumlah & $\%$ \\
\hline $\mathrm{SD} / \mathrm{Ml}$ & 5 & 5 & 10 & 25 \\
\hline SLTP/MTs & 2 & 5 & 7 & 17,5 \\
\hline SLTA & 11 & 9 & 20 & 50 \\
\hline S1 & 2 & 1 & 3 & 7.5 \\
\hline Jumlah & 20 & 20 & 40 & 100 \\
\hline
\end{tabular}

Sumber: olah data primer

Tabel 2 menunjukan jenjang pendidikan dari subjek bervariasi dan dapat diketahui mereka yang berpendidikan SLTA sebanyak (50 persen), SD/MI (25 persen), SLTP/MTs (17,5 persen) dan yang terakhir berpendidikan SI sebanyak (7,5 persen).

\begin{tabular}{ccccc}
\multicolumn{5}{c}{ Tabel 3. Umur } \\
\hline Umur & $\mathrm{L}$ & $\mathrm{P}$ & Jumlah & $\%$ \\
\hline $21-30$ & 3 & 6 & 9 & 22,5 \\
$31-40$ & 6 & 8 & 14 & 35 \\
$41-50$ & 6 & 5 & 11 & 27,5 \\
$51-60$ & 4 & 1 & 5 & 12,5 \\
$<60$ & 1 & - & 1 & 2,5 \\
Jumlah & 20 & 20 & 40 & 100 \\
\hline Sumber: olah data primer & & &
\end{tabular}

Tabel 3 menunjukan subjek yang berumur 31 sampai dengan 40 sebanyak (35 persen), 41 sampai dengan 50 (27,5 persen), 21 sampai dengan 30 (22,5 persen), 51 sampai dengan 60 (12,5 persen) dan subjek yang berumur diatas 60 tahun sebanyak (2,5 persen).

Tabel 4. Penghasilan

\begin{tabular}{lcccc}
\multicolumn{5}{c}{ Tabel 4. Penghasilan } \\
\hline $\begin{array}{l}\text { Penghasilan } \\
\text { (dalam ribuan) }\end{array}$ & $\mathrm{L}$ & $\mathrm{P}$ & Jumlah & $\%$ \\
\hline$>600$ & 2 & 11 & 13 & 32,5 \\
$600-1.200$ & 10 & 7 & 17 & 42,5 \\
$<1.200$ & 8 & 2 & 10 & 25 \\
Jumlah & 20 & 20 & 40 & 100 \\
\hline
\end{tabular}

Sumber: olah data primer

Tabel 4 menunjukan bahwa penghasilan subjek yang kurang dari 600 ribu setiap bulan sebanyak (32,5 persen), penghasilan subjek kisaran 600 ribu sampai dengan 1.2 juta setiap bulan sebanyak (42,5 persen), dan penghasilan subjek lebih dari 1.2 juta setiap bulan sebanyak (25 persen).

Hasil wawancara terhadap 40 subjek perceraian yang terdiri atas 20 janda dan 20 duda menunjukkan bahwa faktor penyebab perceraian karena faktor internal maupun eksternal. Jawaban subjek mengenai sebab perceraian tidaklah tunggal, sebagian subjek memberikan beberapa jawaban atas beberapa faktor penyebab perceraian yang mereka alami. Hal ini logis sebab masalah sosial sering terkait antara satu dengan yang lainnya.

George Levinger (Widayanti 2014) berpendapat bahwa pada umumnya perceraian itu terjadi karena faktor-faktor tertentu yang mendorong suami-istri untuk bercerai. Faktorfaktor dimaksud antara pasangan suami-istri yang satu dengan yang lain saling berbeda.

Dalam penelitian ini subjek memberikan jawaban yang bervariasi dengan alasan yang berbeda-beda yaitu faktor ekonomi, tanggung jawab, pihak ketiga, dan keharmonisan. Hal ini wajar karena setiap problem yang terjadi dalam keluarga berbeda-beda. Jawaban subjek dapat dilihat pada (Tabel 5).

Tabel 5. Rekapitulasi jawaban subjek

\begin{tabular}{cccccc}
\hline \multirow{6}{*}{ No } & Kecamatan & \multicolumn{4}{c}{ Faktor penyebab perceraian } \\
& Ekonomi & Tanggung jawab & Pihak ketiga & Ketidak harmonisan \\
\hline 1 & Tegaldlimo & 4 & 1 & 2 & 3 \\
2 & Tegalsari & 3 & 1 & 4 & 2 \\
3 & Cluring & 5 & 0 & 5 & 0 \\
4 & Banyuwangi & 3 & 4 & 1 & 2 \\
Jumlah & 15 & 6 & 12 & 7 \\
Dalam persen & 37.5 & 15 & 30 & 17.5 \\
\hline
\end{tabular}

Sumber: olah data primer

Permasalahan yang timbul dalam keluarga dapat disebabkan dari dalam maupun luar keluarga itu sendiri, misalnya sikap dan perilaku suami atau istri yang tidak lagi sejalan dengan tuntutan agama dan norma-norma masyarakat, atau karena keadaan biologis dan fisik pasangan yang memungkinkan tidak dapat lagi menjalankan fungsinya sebagai suami maupun istri, atau sudah tidak merasa cocok lagi dengan pasangannya yang semua itu akan mengakibatkan hilangnya rasa saling menghargai sebagai suami istri. 
Emery (1999) mengemukakan bahwa perpisahan suami istri seringkali terjadi karena tidak bisa menyelesaikan konflik intern yang fundamental. Konflik yang timbul sejalan dengan umur kebersamaan suami istri, baik masalah yang datang dari dalam atau masalah dari luar keluarga.

Untuk melihat gambaran deskriptif terhadap faktor-faktor penyebab perceraian yang terjadi berdasarkan hasil penelitian dapat diuraikan sebagai berikut:

\section{Faktor ekonomi}

Hasil penelitian menunjukkan bahwa alasan perceraian karena faktor ekonomi sebesar (37.5 persen). Masalah ekonomi yang muncul yaitu pihak suami yang dianggap tidak mampu mencukupi kebutuhan rumah tangganya, karena penghasilannya pas-pasan sehingga tidak bisa memenuhi kebutuhan keluarga. Pendapatan rata-rata $\mathrm{Rp}$. 1.078.125 perbulan. Dengan kondisi ini sebagian dari mereka baik dari pihak suami maupun istri memutuskan untuk berkerja keluar negeri menjadi TKI maupunTKW dengan harapan bisa memperbaiki ekonomi keluarga, namun yang terjadi sebaliknya bukan ekonomi yang mapan yang didapat malah sebagian di antara mereka tidak terjalin hubungan yang baik dalam keluarga dan berujung pada perceraian.

Lestari (2012) menyatakan bahwa persoalan ekonomi sering menjadi salah satu pemicu utama perceraian. Faktor keberlangsungan dan kebahagiaan sebuah perkawinan sangat dipengaruhi oleh kehidupan finansialnya. Kebutuhan hidup akan dapat tercukupi dengan baik bila pasangan suami isteri memiliki sumber finansial yang memadai. Pendapatan atau penghasilan merupakan suatu hal yang sangat penting dalam keluarga. Dengan pendapatan yang cukup dapat memberikan kepuasan lahir dan batin sebagai pemenuhan segala kebutuhan keluarga.

Dalam kehidupan keluarga peran suami istri sangat penting apalagi dalam mengelola keuangan. masyarakat mempunyai paradigma bahwa nafkah suatu kewajiban suami terhadap istrinya dalam bentuk materi. Hukum membayar nafkah untuk istri, dalam bentuk perbelanjaan, pakaian adalah wajib. Kewajiban ini bukan disebabkan karena istri membutuhkannya bagi kehidupan rumah tangga, tetapi kewajiban ini yang timbul dengan sendirinya tanpa melihat kepada keadaan istri.

Pengaturan nafkah dalam UndangUndang Nomor 1 Tahun 1974 tentang Perkawinan (UU Perkawinan) dapat dilihat dalam Pasal 34 ayat (1) Undang-Undang Perkawinan. Dalam pasal tersebut dikatakan bahwa suami wajib melindungi isterinya dan memberikan segala sesuatu keperluan hidup berumah tangga sesuai dengan kemampuannya. Dalam pengaturan UndangUndang Perkawinan, tidak ditetapkan besarnya nafkah yang harus diberikan, hanya dikatakan sesuai dengan kemampuan si suami.

Hal tersebut diperjelas dalam kitab Undang-Undang Hukum Perdata (KUHPer) juga ada pengaturan mengenai nafkah secara eksplisit, yaitu dalam Pasal 107 ayat (2) KUHPer, yang mengatakan bahwa suami wajib untuk melindungi isterinya dan memberikan kepada isterinya segala apa yang perlu dan patut sesuai dengan kedudukan dan kemampuan si suami.

\section{Faktor pihak ketiga}

Faktor pihak ketiga dimaksud adalah perselingkuhan. Selingkuh, secara etimologi diartikan sebagai perbuatan dan perilaku suka menyembunyikan sesuatu untuk kepentingan sendiri, tidak berterus terang, tidak jujur, dan curang (KBI 2008). Perselingkuhan akhir-akhir ini menjadi bahan perbincangan, sebab perselingkuhan itu sendiri tidak hanya didominasi oleh pria, tetapi juga wanita di segala lapisan dan golongan, bahkan tidak memandang usia.

Gifari (Muahajarah K, 2016) Menyatakan bahwa faktor-faktor terjadinya perselingkuhan antara lain: 1) peluang dan kesempatan; 2) konflik dengan istri; 3) seks tidak terpuaskan; 4) abnormalitas atau animalistis seks; 5) iman yang hampa; 6) karena hilangnya rasa malu.

Masalah perselingkuhan dalam UndangUndang Perkawinan tidak disebutkan secara jelas, namun dampak dari perselingkuhan ini dapat menyebabkan suami isteri terus menerus terjadi perselisihan dan pertengkaran terdapat dalam pasal penjelasan pasal 39 ayat 2 UndangUndang Perkawinan Nomor 1 Tahun 1974 dan berujung pada perceraian.

Dari hasil penelitian diketahui bahwa faktor penyebab perceraian karena pihak ketiga, yaitu (30 persen) dari total keseluruhan subjek. Secara umum faktor yang menyebabkan pasangan suami istri memiliki wanita idaman dan pria idaman lain dalam rumah tangganya, antara lain disebabkan karena kondisi ekonomi yang kurang, dan rendahnya pemahaman tentang hak dan kewajiban seorang suami istri. Hal ini membuat mereka tidak memahami tujuan dari suatu perkawinan. Mereka hanya memandang bahwa tujuan perkawinan sematamata untuk memenuhi kebutuhan biologis tanpa memperhatikan tujuan yang bersifat ibadah.

Menurut Surya (2009) perselingkuhan pada umumnya banyak sekali terjadi pada anggota keluarga yang kurang memiliki kualitas keagamaan yang mantap, lemahnya dasar cinta, sikap egois dari masing-masing, komunikasi kurang lancar dan harmonis, emosi kurang 
stabil, dan kurang mampu membuat penyesuaian diri.

Dengan terjadinya perselingkuhan yang dilakukan baik oleh pihak suami atau istri, pihak yang dirugikan atau disakiti akibat perselingkuhan merasa marah, kecewa, sakit hati, mengalami gangguan fisik, gangguan sosial, ataupun gangguan psikologis, serta sikap tidak saling percaya antara satu dengan yang lain sehingga dapat menimbulkan percekcokan, perselisihan, dan pertengkaran dalam rumah tangganya secara terus menerus dan sulit untuk didamaikan. Jamil A \& Fakhrudin (2015) mengatakan dampak terberat dari cerai gugat adalah penderitaan psikologis yang dialami istri yaitu perasaan kecewa terhadap pernikahan. Dalam keadaan demikian pihak yang merasa tersakiti mengajukan permohonan cerai talak atau gugatan cerai kepada pengadilan.

\section{Ketidakharmonisan}

Secara terminologi keharmonisan berasal dari kata harmonis yang berarti serasi, selaras. Titik berat dari keharmonisan adalah keadaan selaras atau serasi, keharmonisan bertujuan untuk mencapai keselarasan dan keserasian, dalam kehidupan rumah tangga perlu menjaga kedua hal tersebut untuk mencapai keharmonisan rumah tangga (KBI, 2008).

Menurut Fauzi (2006) ketidakharmonisan merupakan alasan yang kerap dikemukakan bagi pasangan yang hendak bercerai. Ketidakhrmonisan bisa disebabkan oleh berbagai hal antara lain, ketidakcocokan pandangan, krisis akhlak, perbedaan pendapat yang sulit disatukan dan lain-lain.

Dari hasil penelitian diketahui bahwa penyebab perceraian yang dikarenakan ketidakharmonisan sebesar (17.5 persen) dari empat faktor penyebab perceraian dan hal tersebut dipicu karena komunikasi yang tidak terjalin dengan baik dan adanya kekerasan dalam rumah tangga (KDRT).

Faktor yang memunculkan ketidak harmonisan hubungan interpersonal dalam keluarga adalah adanya sikap tidak percaya antara suami dan istri yang disebabkan oleh kurangnya kejujuran dan sikap saling terbukadari masing-masing pasangan dalam keluarga sehingga menimbulkan konflik interpersonal dan berujung pada perceraian (Luthfi M. 2017)

Hasil penelitian menunjukan komunikasi yang tidak terjalin dengan baik menjadi faktor ketidakharmonian. Kurangnya komunikasi atau biasa disebut miskomunikasi dapat menyebabkan segala hal yang diinginkan sulit untuk tercapai. Padahal dalam keluarga ada pastinya keinginan untuk hidup tentram dan sejahtera, namun jika tidak ada komunikasi yang baik maka semua itu akan sulit untuk dicapai.
Hal ini dialami oleh subjekyang ditinggal bekerja oleh suami dalam waktu yang lama dan belum dikaruniai anak.

Selanjutnya hasil penelitian menunjukan ketidakharmonisan juga disebabkan oleh KDRT (kekerasan dalam rumah tangga) kepada subjek, berdasarkan penuturannya mereka selalu mendapatkan perlakuan kasar dari suaminya, dan bahkan sering dipukuli hanya karena masalah sepele. Hal inilah yang membuat subjek tidak kuat menanggung derita atas kekerasan oleh suaminya dan akhirnya memutuskan bercerai.Korban KDRT (kekerasan dalam rumah tangga) merasa kekerasan fisik yang dia terima mengakibatkan trauma dan tekanan batin sehingga memilih untuk bercerai agar terlepas dari semua penderitaan yang dapat membahayakan hidupnya.

KDRT (kekerasan dalam rumah tangga), sebagaimana dikemukakan dalam Pasal 1 Undang-Undang Nomor 23 tahun 2004 tentang Penghapusan Kekerasan dalam Rumah Tangga (UU PKDRT) adalah setiap perbuatan terhadap seseorang terutama perempuan, yang berakibat timbulnya kesengsaraan atau penderitaan secara fisik, seksual, psikologis, dan/atau penelantaran rumah tangga termasuk ancaman untuk melakukan perbuatan, pemaksaan, atau perampasan kemerdekaan secara melawan hukum dalam lingkup rumah tangga.

Implikasi dari kekerasan dalam perkawinan ternyata telah berdampak negative kepada perempuan seperti dalam aspek psikologis membuat perempuan stress dan nervous serta apatis, dalam aspek ekonomi membuat perempuan tergantung kepada suami secara mutlak bahkan kadangkala berhenti dari pekerjaannya semula, dalam aspek sosial kemsyarakatan perempuan menjadi terisolasi karena terlalu memikirkan beban intern keluarga (Huda M. 2018).

\section{Faktor tanggung jawab}

Hasil penelitian menunjukkan bahwa alasan perceraian karena faktor tanggung jawab sebesar (15 persen) Secara umum masalah yang dialami subjek untuk memutuskan bercerai yaitu merasa hak-haknya sudah tidak terpenuhi lagi.Hal ini terjadi karena tidak ada tanggung jawab dari suami baik secara moral maupun material. Secara moral mereka ditinggalkan dalam waktu yang lama dan suami tidak memberi kabar berita, sedangkan secara materiil subjek tidak diberikan biaya hidup sehari-hari sebagaimana mestinya.

Tanggung jawab secara harfiah dapat diartikan sebagai keadaan wajib menanggung segala sesuatunya jika terjadi apa-apa boleh dituntut, dipersalahkan, diperkarakan atau juga berarti hak yang berfungsi menerima pembebanan sebagai akibat sikapnya oleh pihak 
lain (KBI 2008)

Tanggung jawab bersifat kodrati, yang artinya tanggung jawab itu sudah menjadi bagian kehidupan manusia bahwa setiap manusia dan yang pasti masing-masing orang akan memikul suatu tanggungjawabnya sendirisendiri. Apabila seseorang tidak mau bertanggung jawab, maka tentu ada pihak lain yang memaksa untuk tindakan tanggung jawab tersebut karena tanggung jawab merupakan sebuah kewajiban yang seharusnya dilaksanakan (Purwaningsih 2015).

Tujuan perkawinan dapat tercapai apabila suami istri mengerti tentang hak dan kewajibannya serta dapat memahami kedudukannya dalam perkawinan. Dalam Undang-Undang Perkawinan Nomor 1 Tahun 1974 Pasal 30 dijelaskan suami istri memikul kewajiban yang luhur untuk menegakkan rumah tangga yang menjadi sendi dasar dari susunan masyarakat.

Kehidupan rumah tangga, mengharuskan masing-masing pihak, baik suami maupun istri, mempunyai kewajiban dan tanggung jawab yang harus dilaksanakan.Kewajiban suami dalam perkawinan adalah memelihara istri dan menyediakan kebutuhan hidup yang layak bagi istri dan anaknya. Sebaliknya seorang istri juga mempunyai kewajiban untuk menjaga atau mengatur rumah tangga, sehingga apapun yang menimpa keluarganya merupakan masalah yang harus ditanggung dan diselesaikan bersama dalam sebuah keluarga.Semua masalah yang timbul menjadi tanggung jawab suami dan istri.

\section{Konsep pendidikan pranikah}

Konsep pernikahan dibutuhkan untuk membangun pemahaman awal masyarakat terhadap pernikahan. Dalam rangka mewujudkan rumah tangga sejahtera bahagia memerlukan pendidikan, bimbingan dan nasihat, baik sebelum melangsungkan pernikahan maupun setelah berumah tangga. Apabila hal tersebut diajarkan kepada remaja yang sedang menjalani proses pendekatan dengan pasangannya, diharapkan memperoleh pelajaran berharga ketika menjalani kehidupan rumah tangga yang sebenarnya.

Pencegahan dan penanggulangan masalah perceraian tidak dapat hanya diserahkan kepada aparat pemerintah saja karena masalah tersebut bersifat multidimensional; sosial, kultural dan moral. Untuk mengatasinya haruslah melibatkan semua unsur, potensi dan pranata sosial dalam komuniti lokal (Fachrina \& Putra R.E 2013)

Pendekatan keluarga adalah salah satu cara untuk memberikan informasi sedini mungkin kepada anak tentang pernikahan. Karena fungsi utama keluarga menurut Peraturan Pemerintah Nomor 21 Tahun 1994 tentang penyelenggaraan pembangunan keluarga sejahtera yaitu fungsi keagamaan, sosialbudaya,cintakasih, melindungi, reproduksi,

sosialisasi dan pendidikan, ekonomi, dan fungsi pembinaan lingkungan

Sekolah merupakan tempat kedua setelah keluarga dalam meberikan pengajaran siswa di bawah pengawasan pendidik atau guru. Sekolah memiliki tanggung jawab yang besar terhadap perkembangan peserta didik dan peningkatan mutu pendidikan di sekolah dengan mendayagunakan komponen-komponen sekolah secara maksimal dalam kehidupan bermasyarakat yang bersifat nyata di sekitarnya.

Dari hasil penelitian disusun konsep materi pendidikan pranikah berbasis pendekatan keluarga dan sekolah.. Adapun konsep materi pendidikan pranikah, yaitu 1) Perencanaan finansial sebelum dan sesudah menikah; 2) Hak dan kewajiban dalam berumah tangga; 3) Hubungan antara suami dengan istri, dengan anak dan keluarga; 4) Kekerasan dalam rumah tangga (KDRT); 4) Gangguan pihak ketiga (WIL/ PIL); dan 5) Keharmonisan dalam rumah tangga

\section{SIMPULAN}

Faktor penyebab perceraian di kabupaten Banyuwangi disebabkan oleh faktor internal maupun eksternal. faktor internal yaitu ekonomi (37.5 persen), tanggung jawab (15 persen), dan keharmonisan (17.5 persen). Sedangkan faktor eksternal yaitu perselingkuhan (30 persen).

Rekomendasi hasil penelitian, disusun konsep pendidikan pranikah berbasis pendekatan keluarga dan sekolah. Hasil penelitian dapat ditindaklanjuti sebagai modal informasi dasar dalam penyusunan model pembelajaran pendidikan pranikah di Kabupaten Banyuwangi

\section{DAFTAR PUSTAKA}

Badan Litbang dan Diklat (2017) https://balitbangdiklat.kemenag.go.id/posti ng/read/495-Tren-Cerai-GugatMasyarakat-Muslim-di-Indonesia [Accessed 4 April 2017].

Bainah, N. (2013). Faktor-faktor penyebab perceraian di Kelurahan Long Ikis, Kabupaten Paser. eJournal SosiatriSosiologi 1 (1):74-83.

Dias, YEP \& Budhy, S. (2013). Aspek-aspek Penyebab Perceraian Gugat di Desa Karangbendo Kecamatan Rogojampi Kabupaten Banyuwangi. Skripsi, Jurusan IImu Kesejahteraan Sosial, Fakultas IImu Sosial dan IImu Politik, Universitas Jember.

Emery, ER. (1999). Marriage, Divorce, and Children Adjustment. 2nd Edition. New York: Prentice Hall International. 
Fachrina \& Putra RE. (2013). Upaya pencegahan perceraian berbasis keluarga luas dan institusi lokal dalam masyarakat Minangkabau di Sumatra Utara. Jurnal Antropologi Indonesia 34 (2):101-111.

Fauzi, DA. (2006). Perceraian Siapa Takut. Jakarta: Restu Agung.

Halimah, (2015). Faktor-faktor penyebab tingginya tingkat gugat cerai di Kecamatan Payung Sekakikota Pekanbaru. Jom FISIP 2 (2):1-15.

Huda, M. (2018). Dampak kekerasan dalam rumah tangga terhadap perempuan di kabupaten Ponorogo. Journal Lentera Unesa 1 (2): 93-106

Jamil, A \& Fakhruddin, (2015). Isu dan realitas dibalik tingginya cerai gugat di Indramayu. Jurnal Multikultural \& Multi Religius Harmoni 14 (2): 138-159.

$\mathrm{KBI}$ (2008). Kamus Besar Bahasa Indonesia. Pusat Bahasa: Jakarta.

Kompas, (2015)

https://regional.kompas.com/read/2015/01 /22/15461501/Banyuwangi.Masuk.Peringk at.Ketiga.Nasional.Angka.Perceraian [Accessed 4 April 2017].

Luthfi, M. (2017). Komunikasi interpersonal suami dan istri dalam mencegah perceraian di Ponorogo. Ejournal Ettisal Unida Gontor 2 (1): 51-63

Lestari, S. (2012). Psikologi Keluarga.Jakarta: Kencana Prenada Media Grup.

Muahajarah, K. (2016) Perselingkuhan suami terhadap istri dan penanganannya. Jurnal SAWWA UIN Walisongo12 (1):1-18.

Puspita, DR. Dharma P, \& Idanati R (2016). Model optimalisasi peran Ketua Rukun tetangga dalam mencegah perceraian. Masyarakat, Kebudayaan \& Politik 29 (4):181-190.

Purwaningsih, (2015). Faktor-faktor yang mempengaruhi gugat cerai dipengadilan agama Kota Bogor. Jurnal Yustisi 1 (1): 11-16.

Pengadilan Agama Banyuwangi, (2017) [Accessed 4 April 2017]. http://pa.banyuwangi.go.id.

Peraturan Pemerintah Nomor 9 Tahun 1975 Tentang Perkawinan.

Sari MN, Yusri, \& Sukmawati I. (2015). Faktor penyebab perceraian dan implikasinya dalam pelayanan bimbingan konseling. Jurnal IKP UNP 3 (1):16-21.

Surur, AT. (2016). Perceraian dini (Sudi terhadap putusan Pengadilan Agama Pekalongan). Jurnal Hukum Islam 14 (1):111-133.

Surya, M. (2009). Bina Keluarga. Bandung: Graha IImu.

Undang-Undang Nomor 1 Tahun 1974 Tentang Perkawinan.
Widayanti, A. (2014). Faktor-faktor penyebab perceraian Keluarga Tenaga Kerja Wanita (TKW) di Desa Citembong, Kecamatan Bantarsari, Kabupaten Cilacap. Skripsi, Jurusan Pendidikan Sosiologi Fakultas IImu Sosial, Universitas Negeri Yogyakarta 